\title{
The Written Text Analysis of Lexical Cohesion and Stylistic Choice of an Indonesian Agony Letter and Its Responses
}

\author{
Bambang Suseno \\ bambangssn@gmail.com \\ English Education Study Program, Universitas Ahmad Dahlan Yogyakarta, \\ Indonesia
}

\section{ABSTRACT}

In order that a reader can get across the message of a written text clearly, the writer is responsible to maintain its coherence as it is one of the significant aspects of the text. This article aims at identifying lexical cohesion and stylistic choice found in an Indonesian agony letter and its responses published in the woman magazine Femina in 1993.

A letter that deals with complaints of marriage problems, its inquiries of suggestions in solving them and its answers is the written text that is analysed in this article. The analysis is conducted to find out what elements are used in it. Coherence applied in this article is lexical cohesion such as synonyms, hyponyms and superordinates, and stylistic choice in the form of choice of words and sentence structures.

Keywords: discourse/text, coherence, lexical cohesion, synonym, hyponym, superordinate.

\section{INTRODUCTION}

This article deals with written text, i.e. "the verbal record of communicative events" (Brown and Yule, 1983: p.190). Because language events do not take place in isolation from other events, rather they operate within a wide framework of human activity, any piece of language is, therefore, part of a situation.' (Spencer and Gregory, 1970: p.75). With respect to this, Hymes' approach, the role of context, in interpreting communicative event would be employed. Moreover, a text would not convey meaningful messages unless it is coherent. The analysis of text coherence with emphasis on lexical cohesion and stylistic choice is carried out.

Hymes' approach to the role of context includes communicative components in which a communicative event occurs. They are channel, code, participants, 
event, setting, form and topic (Hymes, 1964). Later, Hymes also adds audience, key and purpose into the components (Brown and Yule, 1983: p.38). These communicative components, similar to Firth's social context and Lewis' coordinate index, are what Brown and Yule (1983: pp.35-47) consider as context with which the messages of a communicative event can be interpreted. Furthermore, Hymes suggests that context can limit the range of possible interpretation and support intended interpretation as well. (Brown and Yule, 1983). Spencer and Gregory (1970: p.75) agree that 'it is the relationship between the substance and form of a piece of language, on the one hand, and the extra linguistic circumstances in which it occurs, on the other hand, which gives what is normally called 'meaning' to utterances.

The analysis of text coherence focuses on lexical cohesion which is divided into 2 subdivisions: reiteration or elegant variation or noun replacement, and relation which includes: synonym, antonym, hyponym, syntax repetition, stylistic choice (Discourse Analysis lecture notes, 1993), collocation, and equivalent (Tarigan, 1987: p.102)

Because this article will also look at the style of each text, especially at how the writers feel about their problems, it will try to find out if the description is vivid, clear and interesting and if the word choices are accurate and appropriate.

\section{METHOD}

Observation method is applied in this article. It is concerned with an Indonesian agony letter with its responses, given by male and female supervisors, which appeared in Femina published in February, 1993. The letter surveys a topic of a wife who complains because her husband has left her for another woman. The data are analysed to look through the Hymes' features in it-the lexical cohesion and the style.

\section{DISCUSSION}

\section{Hymes' features of context}

The participants of this text are interchanging; at first the writer of the letter is the addressor and the magazine advisors are the addressees. Later, when the letter is replied, she becomes the addressee, and the advisors the addressors. Their interactions, however, are witnessed by wider readers of the magazine, and they are, therefore, the incidental audience of these communicative events.

Using written channel in the form of letters and taking place in a woman magazine as the setting of these communicative events, the participants employ formal code. This is possible because Femina is a magazine that is usually read by settled, married women. Besides, the age of the letter's writer and that of her advisors' is about forty years old. Regardless of the editing process that might have taken place, the age of the letter's writer may affect the sort of language she uses. However, the degree of formality of the text will be discussed later. As it appears in a woman magazine, the communicative event is embedded to larger 
communicative events of the magazine which provides its readers with information and entertainment.

The topic of the communication of the letter is a marital problem. By telling her problem, the addressor is asking for help. Therefore, the letter ends with a question, asking for a suggestion. Subsequently, the advisors respond to her by providing advice and suggestions. The key to this communicative event could only be evaluated by the help-seeker and other readers, the incidental audience of this communication who have similar problems. They will make of the suggestion and see whether they work out.

\section{Lexical Cohesion}

Bahasa Indonesia has sub-divisions of reiteration and relation. However, it is not necessarily all the subdivisions which appear in the text. The tables of the appearance of the lexical cohesion in all texts have been put as appendices. In this discussion an abbreviation is used, i.e. " $\mathrm{S}$ " which stands for 'sentence', for example "S3" showing that it is sentence number 3 that is being discussed.

The noun replacements, like 'the trouble' (S3-Answer Letter I) or 'hasilnya/the result' (S4-Answer Letter I) certainly have cohesive and semantic relationship with their referent of nodes, not only because of the definite article attached to them, but also the definiteness of the noun phrases themselves. As Stoddard (1991: p.30) suggests, the definite noun phrase is more important regarding cohesiveness, because the definite article 'which is the syntactic indicator of one type of cohesive element, is only part of a larger syntactic structure, the definite noun phrase.'

Furthermore, compared to the synonym, for example, noun replacement or elegant variation is very much context-bound, because they have to look at the context where the noun or noun phrase is used and to which referent it refers so that we understand the meaning it bears. For example, 'hasilnya/the result' (S4-Question Letter), in a loose context could be any 'hasil,' but in the context of the question letter, it means the result of her 'discussing the matter nicely with her husband' (Saya sudah berusaha berbicara baik-baik pada suami, tetapi . . . (S4-Question Letter). Similarly, 'tujuannya/the aim' (S8-Answer Letter 1 ) in the context of the answer letter means the aim of considering divorce so that the writer of the question letter will not suffer loss. Such expressions are the superordinates or hyponyms, which could be either a noun, noun phrase, or noun clause, in their contexts. Thus, their relationships are vertical.

The noun replacement of 'wanita itu' with 'madu' (see Question Letter/Appendix 2) shows horizontal relationship. This means although they refer to the same person, this other woman in the question letter does not show superordinate relationship, 'madu' is just a hyponym of a woman, meaning they are not interchangeable.

Unlike noun replacement, synonyms are more predictable. Although they are not in the same context, we will understand that some words can be used somewhat interchangeably, for example wanita-perempuan/woman, or childrenkids/anak-anak. This is because synonym words share some similar semantic properties (Fromkin, et al., 1990: p.209). In the text (Question Letter/Appendix 2)

The Written Text Analysis of Lexical Cohesion and Stylistic Choice of an Indonesian Agony Letter and Its Responses (Bambang Suseno) 
the addressor mentions 'seorang gadis/a girl,' which, although shares some semantic feature with 'a woman,' has an additional semantic feature of being 'unmarried.' However, she uses it appropriately because she refers to the same person whose status changes from a girl to a woman when she, unfortunately, marries her husband.

An easier way to decide whether a word is a hyponym or a superordinate of the other word is that the superordinates do not necessarily have the hyponymous feature, whereas a hyponym must always have a superordinate feature (Nutall 1982: p.78). For example, wanita/woman is a superordinate to madu/husband's second wife,' because 'madu' is always a woman, but a woman is not necessarily a 'madu.' A similar instance is 'suami'and 'pelabuhan'or 'uang' with its hyponomous husband, 'santunan'and 'jaminan hidup'as in the Question Letter.

In the text the use of the verb-noun equivalence is also employed. This, of course, strengthens the cohesiveness among the sentences and the orderliness of ideas. For example, 'menekan' with 'sifat posesif Anda'(Answer Letter 2), and then 'tekanan batin.'

\section{The Stylistic Choice}

What is meant by the style is 'the manner in which a writer characteristically expresses him-/herself which includes word choice, theoretical devices, sentence structure, and other patterns of expression.' (Berry, 1974: p.3). As the data text is supposed to be a communication media, it is concentrating on what is communicated: trying to get the message across. It should be efficient in order to be meaningful. Efficient written communication includes the characteristics of being active, decisive, concrete, objective, and specific (Reddick 1976: p.116). The focus of the following discussion is on the choice of words.

The woman tells her problems in an orderly way to start with: her husband had a relationship with a girl and then continued with their illegal marriage, divorced, and remarried, and now he physically ignores her. However, the establishment of a marriage in Indonesia usually involves many other parties, not only the couple, so that the serious problems which may arise from it must also be made known to the parties. That is why the woman must also consider the other parties, and in her case is the former the formal government body in charge of civil marriage. Thus, too, makes her letter more formal and detailed.

The text (See Question Letter/Appendix 2) also shows clarity and concreteness. For example, the employment of sentences with verb and noun equivalence mentioned previously, although it may sound repetitive because of the repeated use of verbs and nouns like 'menikah/marry with 'surat nikah,' 'dicerai' with 'surat cerai,' and 'membatalkan' with 'pembatalan,' it brings lexical links and, thus, clarity among sentences. (S5-7; S8-12, S11-12) (Tarigan 1987: p.102). Furthermore, from her decisive sentences (S6) 'Saya tidak mau dimadu, juga tidak mau dicerai/1 neither want a divorce nor be two-timed' and then becoming more desperate in (S14) 'Tetapi untuk menerima wanita itu sebagai madu, saya tidak sanggup/but I cannot stand taking her as my husband's second wife,' show how of a dilemma her problem is. For her, losing her husband is not only losing a man, but also financial and social security. As implied from her (S19/S20): she has 
received half of her husband's income since he married the other woman, and her name disappears from her husband's other office as well.

There is also one more formality in her choice of words. The writer uses more standard words like: 'karyawati/worker'; 'menikah/to get married'; 'menjalin hubungan/have a relationship'; 'membatalkan perkawinan/to annul marriage'; 'mohon pertolongan/ask for help' instead of those more colloquial 'pegawai', 'kawin'; 'pacaran', 'membubarkan perkawinan'; 'minta bantuan' respectively, although they are synonymous.

The female advisor (see Answer Letter 1) responds to her client's problem in a calm tone throughout her utterances. Firstly, she gives a general account of what alternatives a wife, whose husband is going to marry other woman, has. Then, she comes to her client's case and tells her what considerations she can think of, that is by showing her client the possibility of a having a divorce. It could be implied from her sentence, although she stays cool and does not say any bad words of either the husband or the wife, she cannot tolerate her client's husband's misbehavior: (S6) 'Daripada Anda menanggung sakit hati terus, suatu perceraian mungkin bisa jadi pertimbangan/Rather than hurting your feeling for so long, may be you can consider a divorce.' She hedges with 'mungkin/may be' because she later admits that the choice is not the best as (s10) "Memang perceraian adalah perbuatan yang paling dibenci Allah/It's true, a divorce is the most despised deed by Allah." However, she reasons her suggestions with (S11) "the unhealthiness of living with constant hatred, distressed, and bitter"; because such a situation will poison her and her children's lives.

Also in suggesting her advice, she is concrete and practical: (S7) "to contact her husband's office so as not to lose the palimony she deserves," (S9) "to get the children involve in the decision without indoctrinating them with her own feeling." She uses "santunan/palimony"; bungkam/silent"; "mandiri/independent"; "menghidupi/live on"; "menggugat/to sue for"; "berunding/to discuss"; "cerna/understand"; instead of their more informal synonyms: "bantuan"; "diam"; "berdiri sendirl"; "membiayal"; "menuntut"; "berbicara"; "dimengerti", respectively. However, she also uses figurative expressions, for example: " ... gigit jari,, suami terbang, uang pun melayang/biting her nail: her husband flies, the money buoys up, literally means, she is left with nothing losing both her husband and his money.

There are more figurative expressions used by the male advisor: "mentahmentah"; "dipukulK.O.; "gerah"; and 'udara segar," these phrases literally mean "intentionally or bluntly"; "let somebody down"; "restless and unhappy" and "new situation/freedom-and this could be new woman."

The male advisor is more introspective about the problem so that he suggests she ask herself why this problem arose: S9) "Do you push him around too much," "Is it your possessiveness that makes him restless and want to feel some freedom from you? "He does not explicitly suggests a separation, but he suggests that she should be more careful: (S16) "If he comes back to you, you still have to be watchful with his behaviour (his liking of "fresh air")." 


\section{CONCLUSION}

As the text shares Hymes' features, we could have the context of interpreting the messages. The text uses lexical cohesion and has its own style in employing lexical ties. Also, it has repetition of nouns and verbs, and other elegant variations of using noun clauses instead of just phrase to refer to another noun clause.

The difference in style, especially when we pay attention to the female advisors is calmer than the male one. However, the ways she gives suggestions shows their practicality. Although the client is concerned about her sexual relationship, and directly and openly tells her advisors, they do not explicitly respond to it. They let their client infer herself from their suggestions: whether she should consider separation or preserve the marriage with a new awareness. Once the problem is solved, either way, the sexual matter will presupposedly be overcome as well.

\section{REFERENCES}

Berry, T. E. (1974). The Craft writing. New York: McGraw-Hill.

Brown, G. \& Yule, G. (1983). Discourse analysis. Cambridge: Cambridge University Press.

Fromkin, V., Rodman R., and Hyams N. 2003. An introduction to language, 7th ed. Boston: Thomson Wadsworth.

Fromkin, V., Rodman, R., \& Hyams, N.M. (1990). An Introduction to language. Sidney: Holt, Rinehart and Winston.

Hymes, D. (1964). Towards ethnographies of communication: The analysis of communicative events. In P. Giglioli (Ed.), Language and Social Context (pp.21-43). Baltimore: Penguin Books Ltd.

Kridalaksana, H. (1982) (2011). Kamus linguistik. Jakarta: PT Gramedia Pustaka Utama.

McCarthy, M. (1991). Discourse analysis for language teachers. Cambridge: Cambridge University Press.

Nutall, C. (1982). Teaching reading skills in a foreign language. London: Heinemann.

Perrin, R. (1985). Sharing ideas: A Rhetoric for beginning writers. New York: Holt, Rinehart and Winston.

Reddick, B. (1976). Effective writing style. New York: Richard Rosen.

Spencer, J. and M.J. Gregory. (1970). An Approach to the study of styles. In D.C. Freeman (Ed.), Linguistics and literary style (pp.73-95). New York: Holt, Rinehart, and Winston.

Stoddard, S. (1991). Text and texture: Patterns of cohesion. New Jersey: Ablex.

Tarigan, H.G. (1987). Pengajaran wacana. Bandung: Angkasa.

Wyrick, J. (1987). Steps to writing well: A Concise guide to composition. New York: Holt, Rinehart and Winston. 